\title{
PENERAPAN NILAI-NILAI ISLAM DALAM PEYELESAIAN \\ SENGKETA MAWAH (STUDI KASUS DI KABUPATEN PIDIE)
}

\author{
APPLICATION OF ISLAMIC VALUES IN THE SETTLEMENT
}

OF THE MAWAH DISPUTE (CASE STUDY IN PIDIE DISTRICT)

\section{MUHAMMAD NOUVAL, FAISAL DAN \\ MANFARISYAH}

(Mahasiswa Hukum Perdata Magister Hukum, Dosen Fakultas Hukum,

Dosen Fakultas Hukum Universitas Malikussaleh).

Jl. Jawa, Blang Pulo, Kecamatan Muara Satu, Aceh, 24335

Email: muhdnopal753@gmail.com

\begin{abstract}
One of the collaborative activities in the Acehnese community is mawah, Pidie District is one of the places in Aceh where mawah practices are found. The mawah agreement does not rule out the possibility of disputes due to unwritten agreements or breaking promises in the distribution of results that occur in the community. If a dispute occurs within the Acehnese community (including the mawah dispute) it will be resolved through the customary court before being handed over to the police. This study aims to analyze the mawah dispute resolution procedure in Pidie district and how Islamic law reviews the mawah dispute resolution in Pidie district. The results of the study indicate that the settlement of disputes both minor and civil crimes (including mawah) in Pidie Regency must be taken through the gampong customary court with the principles of consensus and peace.
\end{abstract}

Keyword: IslamicValues, Mawah Dispute Resolution

\section{Intisari}

Salah satu kegiatan kerjasama pada masyarakat Aceh adalah mawah, Kabupaten Pidie merupakan salah satu tempat di Aceh dimana ditemukan praktik mawah. Perjanjian mawah tidak menutup kemungkinan terjadinya sengketa karena perjanjian yang tidak tertulis atau ingkar janji dalam pembagian hasil terjadi didalam masyarakat. Jika terjadi sengketa di dalam masyarakat Aceh (termasuk sengketa mawah) akan diselesaikan melalui peradilan adat sebelum diserahkan kepihak kepolisian. Penelitian ini bertujuan untuk menganalisis prosedur penyelesaian sengketa mawah di kabupaten pidie. Hasil penelitian menunjukkan 
bahwa penyelesaian sengketa baik pidana ringan maupun perdata (termasuk mawah) di Kabupaten Pidie harus ditempuh melalui peradilan adat gampong dengan prinsip mufakat dan perdamaian.

Kata Kunci: Nilai-Nilai Islam, Penyelesaian Sengketa Mawah.

\section{Latar Belakang Masalah}

Islam sebagai sistem kehidupan yang universal, integral, dan komprehensif telah menetapkan tatanan yang utuh untuk kehidupan manusia. Sebagai way of life, Islam menata segala hal yang berkaitan dengan kehidupan, dari hal yang paling sederhana hingga urusan yang paling rumit sekalipun. Baik itu dalam aspek politik, pendidikan, seni, budaya dan ekonomi.

Aktivitas ekonomi dalam Islam tidak hanya persoalan materi saja, tetapi juga aspek spiritual dan moral merupakan persoalan yang sangat urgen. Karena Aqidah Islam menjadi motivasi kuat yang mendorong seseorang untuk bekerja. Aktivitas ekonomi meliputi tiga kegiatan penting yang terdiri dari produksi, distribusi dan konsumsi. Dalam Kamus Besar Bahasa Indonesia kata bisnis antara lain diartikan sebagai usaha dagang, usaha komersial dalam perdagangan. Bentuk usaha atau bisnis juga dapat dilakukan dengan kerjasama.

Salah satu kegiatan kerjasama pada masyarakat Aceh adalah mawah. Kegiatan tersebut telah ada sejak abad ke 16 dan masih eksis dimasyarakat sampai sekarang. ${ }^{1}$ Praktik mawah di Aceh sangat populer dan telah menjadi tradisi. Mawah dalam masyarakat Aceh memiliki tiga bentuk umum kegiatan, terdiri dari pengelolaan sawah, kebun dan binatang ternak. ${ }^{2}$

Praktik mawah memang sangat populer di Aceh, bahkan setiap daerah di Aceh memiliki pelaksanaan dan pembagian hasil dengan cara yang berbeda antara satu dengan daerah lainnya. Mawah dalam konteks adat dan tradisi Aceh merupakan bentuk kerja sama antara dua orang atau kelompok dalam rangka mengelola barang yang berharga, hal ini bertujuan untuk memperoleh keuntungan

${ }^{1}$ Abdurrahman, 2014, "Praktek Mawah melalui Mudharabah dalam Masyarakat Aceh", Tesis, Fakultas Hukum Universitas Sumatera Utara, Medan, hlm.3.

${ }^{2}$ Saifuddin, Majelis Permusyawaratan Ulama Aceh, http://mpu.acehprov.go.id/., Diakses pada tanggal 27 september 2016. 
bagi kedua belah pihak. Kegiatan mawah memiliki eksistensi sampai saat ini karena proses perjanjian yang mudah karena didasari oleh rasa saling percaya antara pemilik harta dan pengelola serta memiliki nilai ekonomis yang tinggi bagi pihak pengelola yang tidak memiliki modal, khususnya dalam bentuk pengelolaan hewan ternak seperti, kerbau, sapi, kambing dan hewan ternak lainnya. ${ }^{3}$

Perjanjian mawah tidak menutup kemungkinan terjadinya sengketa, perjanjian yang tidak tertulis atau ingkar janji dalam pembagian hasil terjadi didalam masyarakat. Pembagian hasil perkebunan atau pertanian tidak sesuai dengan kesepakatan awal atau hewan ternak digelapkan dengan pengakuan pengelola bahwa hewan tersebut mati atau hilang sering terjadi dalam praktek mawah di Aceh.

Undang-undang Nomor 11 Tahun 2006 tentang Pemerintahan Aceh telah memberikan landasan yang lebih kuat dalam pembinaan kehidupan adat dan adat istiadat di Provinsi Aceh. Berdasarkan Undang-Undang tersebut maka dibentuklah Lembaga Adat yang ditetapkan melalui Qanun Aceh Nomor 10 Tahun 2008 tentang Lembaga Adat. Lembaga ini berfungsi sebagai wahana partisipasi masyarakat dalam penyelenggaraan pemerintahan, pembangunan, pembinaan masyarakat, dan penyelesaian masalah-masalah sosial kemasyarakatan. ${ }^{4}$ Maka apabila terjadi sengketa dalam masyarakat Aceh, Pemangku Adat ${ }^{5}$ pada masing-masing daerah dapat menyelesaikan permasalahan atau sengketa tersebut.

Kabupaten Pidie merupakan salah satu tempat di Aceh dimana ditemukan praktik mawah, Pidie dipilih sebagai tempat penelitian dengan beberapa alasan yaitu; pertama, Pidie termasuk salah satu wilayah yang menyandang persentase produktivitas penghasil tanaman padi tertinggi di Provinsi Aceh. Kedua, secara historis pidie dikenal sebagai komunitas masyarakat Aceh yang memiliki entitas

\footnotetext{
${ }^{3}$ Ibid

${ }^{4}$ Qanun Aceh Nomor 10 Tahun 2008 tentang Lembaga Adat

5 Pemangku adat adalah orang yang menduduki jabatan pada lembaga-lembaga adat.lembaga-lembaga adat sebagaimana yang dimaksud dalam Qanun Aceh Nomor 10 Tahun 2008 pada ayat (2) adalah: Majelis Adat Aceh, Imeum Mukim atau nama lain, Imeum Chiek atau nama lain, Keuchiek atau nama lain, Tuha Peut atau nama lain, Tuha Lapan atau nama lain, Imeum meunasah atau nama lain, Keujruen Blang atau nama lain, Panglima Laot atau nama lain, Pawang Gle/Uteun atau nama lain,Petua Seuneubok atau nama lain, Haria Peukan atau nama lain, Syahbanda atau nama lain.
} 
tersendiri. Ketiga, masyarakat Pidie adalah petani handal yang menjadikannya sebagai lumbung padi utama bagi Aceh pada masa kesultanan Aceh sehingga memperoleh status negeri beras. Berdasarkan hal ini tentunya banyak terjadi praktek kerjasama antar masyarakat dalam praktek mawah. Oleh sebab itu, penelitian ini berupaya untuk memastikan bahwa praktik penyelesaian sengketa mawah dilokasi penelitian telah diaplikasikan sesuai dengan nilai-nilai dan normanorma dalam masyarakat yang sejalan dengan Hukum Islam.

Berdasarkan latar belakang yang dikemukakan diatas, maka penulis tertarik untuk melakukan penelitian lebih lanjut yang berjudul "Penerapan Nilai-Nilai Islam Dalam Penyelesaian Sengketa Mawah ( Studi Kasus di Kabupaten Pidie).

\section{Metode Penelitian}

Jenis penelitian dalam artikel ini adalah kualitatif, dengan pendekatan yuridis empiris mengkaji penerapan nilai-nilai hukum Islam dalam penyelesaian sengketa mawah di Kabupaten Pidie, metode pengumpulan data dengan wawancara dan analisis data dilakukan secara kualitatif.

\section{Hasil Penelitian dan Pembahasan}

\section{a. Pengertian Penyelesaian Sengketa}

Penyelesaian sengketa adalah suatu penyelesaian perkara yang dilakukan oleh satu pihak dengan pihak lainnya. Pada dasarnya penyelesaian sengketa dapat dilakukan dengan menggunakan dua cara yaitu penyelesaian sengketa melalui lembaga litigasi (melalui pengadilan) dan penyelesaian sengketa melalui cara nonlitigasi (di luar pengadilan).

\section{1). Penyelesaian Sengketa Secara Litigasi}

Dalam peraturan perundang-undangan belum ada yang memberikan definisi mengenai litigasi, namun dapat dilihat dalam pasal 6 ayat (1) UU 30 Tahun 1999 tentang Arbitrase yang pada intinya menjelaskan bahwa sengketa dalam bidang keperdataan dapat diselesaikan oleh para pihak yang bersengketa melalui alternatif 
penyelesaian sengketa yang dilatarbelakangi oleh itikad baik dengan mengesampingkan penyelesaian sengketa secara litigasi di Pengadilan Negeri. ${ }^{6}$

Penyelesaian sengketa secara litigasi merupakan upaya penyelesaian sengketa melalui Lembaga Pengadilan. Menurut Dr. Frans Hendra Winarta, S.H.,M.H. dalam bukunya yang berjudul Hukum Penyelesaian Sengketa, mengatakan bahwa litigasi merupakan penyelesaian sengketa secara konvesional didalam dunia bisnis seperti dibidang perbankan, perdagangan, minyak, gas dan sebagainya. Proses litigasi menempatkan para pihak yang saling berlawanan satu sama lain. Selain itu, penyelesaian sengketa secara litigasi merupakan langkah akhir (ultimum remidium) setelah upaya-upaya alternatif penyelesaian sengketa tidak membuahkan hasil. ${ }^{7}$

\section{2). Penyelesaian Sengketa Secara Non-Litigasi}

Rachmadi usman, mengatakan bahwa selain melalui Litigasi (pengadilan), penyelesaian sengketa juga dapat diselesaikan melalui proses Non-Litigasi (diluar pengadilan), yang biasanya disebut dengan Alternative Dispute Resulution (ADR) di Amerika, sedangkan di Indonesia biasanya disebut dengan Alternatif Penyelesaian sengketa (APS). ${ }^{8}$

Terhadap penyelesaian sengketa diluar pengadilan, telah memiliki landasan Hukum yang diatur dalam UU 30 Tahun 1999. Walapun pada prakteknya penyelesaian sengketa di luar pengadilan merupakan salah satu dari pada nilai-nilai budaya, kebiasaan atau adat masyarakat Indonesia dan hal ini sejalan dengan citacita masyarakat Indonesia sebagaimana tercantum di dalam Undang-Undang Dasar Tahun 1945. Cara penyelesaian sengketa tersebut adalah dengan cara musyawarah dan mufakat untuk mengambil suatu keputusan. Misalnya dalam forum runggun adat yang menyelesaikan suatu masalah yang dihadapi dengan cara musyawarah dan secara kekeluargaan, dalam menyelesaikan suatu masalah yang dihadapi oleh

\footnotetext{
${ }^{6}$ Bunyi Pasal 6 ayat (1), "Sengketa atau beda pendapat dapat diselesaikan oleh para pihak melalui alternatif penyelesaian sengketa yang didasarkan pada itikad baik dengan mengesampingkan penyelesaian sengketa secara litigasi di Pengadilan Negeri.

${ }^{7}$ Frans Hendra Winarta, 2012, Hukum Penyelesaian Sengketa Arbitrase Nasional Indonesia dan Internasional, Sinar Grafika, Jakarta, hlm. 1 dan 2.

${ }^{8}$ Rachmadi Usmani, 2012, Mediasi di Pengadilan : Dalam Teori dan Praktik, Sinar Grafika, Jakarta, hlm.8.
} 
masyarakat setempat dikenal dengan adanya Lembaga Hakim Perdamaian yang secara umum berperan sebagai mediator dan konsiliator. Oleh karena itu, masuknya konsep ADR di Indonesia tentu saja dapat dengan mudah diterima oleh masyarakat Indonesia. $^{9}$

\section{b. Prosedur Penyelesaian Sengketa Dalam Islam}

Dalam sejarah Islam, disaat terjadi perbedaan pendapat atau persengketaan antara satu pihak dengan pihak lainnya baik itu dalam bidang keluarga ataupun dalam bidang bisnis (muamalah). Ada berbagai macam cara penyelesaian sengketa yang berkembang dimasyarakat yang masing-masing mempunyai keunggulan dan kelemahan tertentu, penyelesaian sengketa dalam Islam mengandung makna baik itu sebagai lembaga, proses maupun produk. Maka lembaga yang dapat menyelesaikan masalah tersebut adalh melalui mekanisme perdamaian (sulh), arbitrase (tahkim), dan pengadilan (Al-qada). ${ }^{10}$

1). Konsep Perdamaian (sulh)

konsep Sulh (perdamaian) seperti yang terdapat didalam kitab-kitab fiqih merupakan suatu doktrin utama Hukum islam dalam konteks muamalah untuk menyelesaikan persengketaan. Perdammain bukanlah hanya pranata hukum positif semata, melainkan lebih kepada sifat fitrah manusia, yang pada dasarnya manusia memang menginginkan perdamaian. ${ }^{11}$

Sulh secara bahasa adalah meredam pertikaian. Sulh menurut istilah artinya akad atau perjanjian yang dibuat untuk menyelesaikan pertikaian antara dua pihak yang bersengketa guna untuk mencapai kesepakatan damai. ${ }^{12}$ Menurut Sayyid Sabiq, sulh adalah akad yang mengakhiri persengketaan antara dua pihak. ${ }^{13}$

9 Rika Lestari, "Perbandingan Hukum Penyelesaian sengketa Secara Mediasai di Pengadilan dan di Luar Pengadilan di Indonesia", Jurnal Ilmu Hukum, Vol. .3, No.2, hlm. 219.

${ }^{10}$ Yusna Zaidah, 2015, Penyelesaian Sengketa Melalui Peradilan dan Arbitrase Syariah di Indonesia, Aswaja Pressindo, Yogyakarta, hlm.5.

${ }^{11}$ Abdul Manan, 2012, Hukum Ekonomi Syariah Dalam Perspektif Kewenangan Peradilan Agama, Kencana Prenada Media, Jakarta, hlm.437.

${ }^{12}$ AW Munawir, Kamus Al-Munawir, Yogyakarta,:Pondok Pesantren Al-Munawir, 1984, hlm.437.

${ }^{13}$ Sayyid Sabiq, 2000, Fiqih Sunnah, Juzu' 3, Dar Al-Fath, Kairo, hlm.210. 
Sulh merupakan kesepakatan para pihak yang bersengketa untuk membuat kesepakatan damai. Imam Zakariya menyebutkan sulh merupakan akad yang dibuat oleh para pihak yang membuat kesepakatan untuk mengakhiri persengketaan mereka. ${ }^{14}$ Akad atau perjanjian perdamaian yang sudah dibuat oleh peihak yang bersengketa tersebut harus diberitahukan kepada hakim yang menyelesaiakan sengketanya, hal ini supaya hakim tidak melanjutkan proses pemeriksaan pemeriksaan sengketanya secara litigasi. Selanjutnya akad Sulh atau perjanjian perdamaian tersebut akan dikuatkan oleh hakim yang memeriksa sengketa tersebut sehingga mempunyai kekuatan hukum dan bisa dilaksanakan oleh para pihak.

Kedudukan sulh dalam Islam sangat jelas karena ini merupakan salah satu jalan penyelesaian sengketa yang sangat disukai oleh pihak-pihak yang ingin menyelesaikan persengketaan. Islam sangat menitikberatkan pemakaian konsep sulh ini. Mekanisme Sulh sering dipakai dalam persengketaan yang melibatkan kontrak perdagangan. ${ }^{15}$

2). Konsep Arbitrase (TahKim)

Penyelesaian sengketa melalui jalan Tahkim telah lama dipraktekkan sejak zaman Rasulullah Saw. Menurut bahasa, Tahkim bermakna permintaan memutuskan hukuman. Menurut Wahbah Al Zuhaili, seorang ulama kontemporer dalam bidang Hukum Islam, Tahkim adalah apabila kedua belah pihak yang bersengketa mengangkat seseorang untuk menyelesaiakan persengketaan antar mereka. ${ }^{16}$ Tahkim juga bermakna Tauliyah yang dibuat oleh kedua belah pihak yang bersengketa kepada seorang hakam. Hakam merupakan pendamai yang mempunyai kuasa untuk menetapkan hukum serta mengambil keputusan terhadap kedua belah pihak yang bersengketa.

Lebih lanjut dijelaskan pula bahwa tahkim adalah berlindungnya kedua belah pihak yang bersengketa kepada seorang yang mereka sepakati dan disetujui serta rela menerima keputusan orang yang ditunjuk untuk menyelesaikan sengketa

\footnotetext{
${ }^{14}$ Abu Zakaria bin Yahya-Nawawi, 2009, Mugni Al-Muhtaj, dikutip dari Syahrial Abbas, Mediasi Dalam Perspektif Hukum Syariah, Hukum Adat, dan Hukum Nasional, Kencana, Jakarta, hlm.160.

15 Rahma Ismail, Mekanisme Penyelesain Pertikaian Alternatif dan Perbandingannya dengan Islam, Makalah Undang-Undang Jilid 1, 2003, UKM, Bangi, 2003, hlm.47.

${ }^{16}$ Wahbah Al-Zuhaili, 1997, Al-Fiqh al-Islamiyah wa Adillatuh, Damaskus, Dar al Fikr.
} 
mereka, atau didefinisikan pula sebagai tempat berlindungnya kedua belah pihak yang bersengketa kepada seseorang yang mereka tunjuk (sebagai penengah) untuk memutuskan atau menyelesaikan persengketaan yang terjadi diantara mereka. Kedua definisi diatas menunjukkan bahwa pengangkatan dan pemilihan seorang juru damai (hakam) dilakukan secara sukarela oleh kedua belah pihak yang terlibat persengketaan. ${ }^{17}$

Jika dilihat dari sejarah, tahkim merupakan peninggalan tradisi Arab pada masa pra Islam yang kemudian diIslamkan oleh nabi Muhammad SAW. Dalam masyarakat pra Islam, belum ada kekuasaan politik dan sistem peradilan yang terorganisir. Walaupun demikian, jika terjadi perselisihan mengenai hak milik, pelanggaran hukum selain pembunuhan dan sengketa hak waris, maka persengketaan tersebut bisa diselesaikan dengan bantuan juru damai yang ditunjuk oleh pihak-pihak yang bersengketa. Untuk melaksanakan tugas sebagai juru damai tidak ada pejabat resmi. Artinya, jika terjadi persengketaan maka akan ditunjuk juru damai yang bertugas menyelesaikan persengketaan tersebut, juru damai tersebut dinamai dengan sebutan hakam. ${ }^{18}$

Penunjukan hakam sebagai orang yang menyelesaikan persengketaan bukan ditetapkan oleh pihak pemerintah, akan tetapi ditunjuk lansung oleh pihak yang bersengketa. Oleh sebab itu, hakam atau lembaga hakam bukanlah lembaga resmi pemerintahan, hakam merupakan lembaga swasta. Aktifitas penunjukan itu disebut tahkim,dan orang yang ditunjuk disebut hakam. Penyelesaian sengketa yang dilakukan oleh hakam pada abad moderen dikenal dengan istilah Arbitrase. ${ }^{19}$ fungsi hakam sangat berkaitan erat dengan kewenangan hakam itu sendiri, adapun kewenangan hakam adalah menyelesaikan menyelesaian pertikaian yang diajukan oleh para pihak yang bersengketa kepadanya. Sengketa-sengketa tersebut adalah sengketa yang berkaitan dengan hak perorangan, satu hal yang menjadi tujuan

${ }^{17}$ Abdul Aziz Dahlan et al, 1997, Ensiklopedia Hukum Islam, PT. Ichtiar Baru Van Hoeve, Jakarta, hlm.157.

18 Ramlan Yusuf Rangkuti, 2001, "Sistem Penyelesaian Sengketa Ekonomi Islam, Instrumen Penting Bagi Konsep Ekonomi Islam Mendatang”, Jurnal Ilmu Syariah dan Hukum, hlm.143.

${ }^{19}$ Abdul Aziz Dahlan et al, 1997, Insiklopedia Hukum Islam, PT. Ichtiar Baru Van Hoeve, Jakarta, hlm.159. 
utama praktek penyelesaian sengketa melalui jalan arbitrase adalah menyelesaikan sengketa secara damai. Berdasarkan prinsip tersebut, sengketa yang kan diselesaikan oleh hakam adalah sengketa yang pada dasarnya bisa diselesaikan dengan cara damai, sengketa-sengketa yang bisa didamaikan seperti sengketa yang bersangkutan dengan harta benda dan sengketa yang sama sifatnya dengan itu.

\section{3). Lembaga Peradilan Syariah (Al-Qada)}

Hukum Islam tidak dapat dipisahkan dari realitas masyarakat, untuk dapat ketentuan-ketentuan yang berlaku didalam hukum Islam diperlukan lembaga peradilan yang dalam Islam disebut Al-Qada'. Al-Qada' dibutuhkan untuk mengatur masalah-masalah yang tumbuh didalam masyarakat yang berkaitan dengan tingkah laku manusia yang pada dasarnya bersifat mementingkan diri sendiri. Lembaga peradilan ini merupakan wujud dari realisasi sosial. Dalam hal ini, terlihat bahwa Hukum Islam bukan hanya sekedar ketentuan yang dipaksakan dari luar masyarakat, hal ini dikarenakan lembaga peradilan yang menguji berlaku atau tidaknya ketentuan hukum tersebut ditentukan oleh bentuk kekuasaan yang ada dalam masyarakat. Negara sebagai sebuah organisasi kekuasaan merupakan cerminan dari suatu realitas sosial. Kekuasaan yang ada pada lembaga peradilan tidak dapat dipisahkan dari kekuasaan yang ada pada suatu negara. Menurut konsep Fiqh, kekuasaaan lembaga peradilan merupakan merupakan limpahan dari kekuasaan umum. $^{20}$ Kekuasaan lembaga peradilan baru ada apabila sudah memperoleh perlimpahan wewenang dari kekuasaan politik tersebut. Dalam Islam, hal tersebut terlihat dari pengangkatan para hakim pada masa awal Islam oleh para penguasa.

Sebenarnya jika dilihat dari sejarah, keberadaan Lembaga Peradilan Syariah telah diakui sejak lama di Indonesia. Pemerintah belanda membentuknya dengan staatblad (LN) 1882 No. 152 jo staablad 1937 untuk peradilan Agama di jawa dan madura. Setelah Indonesia merdeka, pemerintah membentuk peradilan Agama untuk selain Jawa-Madura dengan peraturan pemerintah Nomor 45 Tahun 1975.

\footnotetext{
${ }^{20}$ Salam Madkur, 1964, Al-Qadha' fi al-Islam, kairo, Dar al-Nahdhah al-Arabiyah, hlm.30-
} 31. 
Akan tetapi, dalam peraturan-peraturan tersebut belum diatur tentang hukum acara mengenai tata cara memeriksa, mengadili, dan menyelesaikan persengketaan. Sehingga para Hakim peradilan Agama mengambil rujukanhuum acara yang ada didalam kitab fiqih yang dalam penerapannya berbeda antara pengadilan Agama yang satu dnegan perdailan Agama yang lainnya. ${ }^{21}$ Sedangkan produk hukum Undang-Undang Nomor 50 Tahun 2009 atas perubahankedua Undang-Undang Nomor 7 Tahun 1989 tentang peradila Agama, lahir dari konfigurasi politik yang demokratis dan karakter hukum yang responsif. Maka jika dilihat dari perspektif materi hukum, politik hukum pemerintah bersifat otonom dan responsif, dimana produk hukum ini mencerminkan harapan masyarakat dan keadilan. ${ }^{22}$

Peradilan Syariah adalah peradilan Islam di Indonesia, sebab dari jenis-jenis perkara yang boleh diselesaikan seluruhnya merupakan jenis perkara menurut agama Islam. Lebih jelasnya, Pengadilan Syariah merupakan peradilan Islam limitif yang disesuaikan dengan keadaan di Indonesia. Jika ditinjau dari asas-asas hukum acara, tentunya ada prinsip-prinsip kesamaannya secara umum disamping secara khusus tentu adapula perbedaan antara hukum acara peradilan umum dan hukum acara perdata peradilan agama. ${ }^{23}$ Dengan kata lain, peradilan Agama merupakan salah satu pelaksanaan kekuasaan kehakiman yang ikut berfungsi dan berperan dalam menegakkan keadilan, kebenaran, ketertiban, dan kepastian hukum mengenai perkara perdata Islam tertentu, karenanya, Peradilan Agama ini disebut peradilan khusus.

Salah satu kekhususan yang diberikan Negara kepada Provinsi Aceh adalah hak dan peleuang untuk membentuk Mahkamah Sya'iyah sebagai peradilan Syariat Islam. Ketentuan ini dijelaskan dalam Undang-Undang Nomor 11 Tahun 2006 tentang Pemerintahan Aceh (UU Pemerintahan Aceh), khususnya dalam Pasal 128 ayat (2) yang menyebutkan bahwa "Mahkamah Syar'iyah merupakan pengadilan bagi setiap orang yang beragama Islam yang berada di Aceh”.

${ }^{21}$ Aris Bistania, 2013, Hukum Acara Peradilan Agama dalam Kerangka Fiqh al-Qadha, Pt. Raja Grafindo Persada, Jakarta, hlm.2.

${ }^{22}$ Abdul Halim, 2016, Peradilan Agama dalam Politik Hukum di Indonesia, PT. Grafindo Persada, Jakarta, hlm.164.

${ }^{23}$ Roihan A Rasyid, 2016, Hukum Acara Peradilan Agama, Edisi Terbaru, PT.Garfindo Persada, Jakarta, hlm.6-7. 
Peradilan Syari'at Islam di Aceh yang dilakukan oleh Mahkamah Syar'iyah adalah pengadilan khusus dalam lingkungan peradilan Agama, Mahkamah Syar'iyah juga memiliki kekuasaan untuk melaksanakan wewenang peradilan Agama dan juga memiliki sebahagian wewenang peradilan umum. ${ }^{24}$

Mahkamah Syar'iyah juga menganut tiga macam peradilan, yaitu tingkat pertama, tingkat banding dan tingkat khasasi ke Mahkamah Agung. Mahkamah Syar'iyah di Aceh sudah lebih luas dalam melaksanakan kewajiban penetapan hukum-hukum Islam, terhadap hukum keluarga, hukum perdata (mu'amalah) dan hukum pidana (jinayat). Mahkamah Syar'iyah juga berwenang mengadili serta memutuskan perkara-perkara tindak pidana (jarimah) seperti penyebaran aliran sesat (bidang aqidah), tidak melaksanakan shalat jum'at tiga kali berturut-turut tanpa uzur syar'i (bidang ibadah), meyediakan fasilitas kepada orang muslim tanpa uzur syar'i untuk tidak berpuasa (bidang ibadah).

\section{c. Prosedur Penyelesaian Sengketa Mawah di Kabupaten Pidie}

Tidak ada seorangpun yang ingin terlibat dalam persengketaan yang akan menimbulkan permasalahan dan rentan terjadinya permusuhan. Namun faktanya, sengketa dapat saja terjadi pada siapapun dan dimana saja. Secara pengertian, sengketa adalah suatu keadaan dimana ada pihak yang merasa dirugikan oleh pihak yang lain yang kemudian pihak tersebut menyampaikan ketidakpuasan ini kepada pihak lainnya yaitu pihak kedua. Jika situasi ini menunjukkan perbedaan pendapat, maka terjadilah apa yang dinamakan dengan sengketa. Menurut Takdir Rahmadi, sengketa adalah situasi dan kondisi diamana orang-orang saling mengalami perselisihan yang bersifat faktual maupun perselisihan-perselihan yang ada pada persepsi mereka saja. ${ }^{25}$

${ }^{24}$ Lihat penjelasan Pasal 1 angka 2 Pasal 3A Undang-Undang Nomor 3 Tahun 2006 tentang perubahan atas Undang-undang Nomor 7 Tahun 1989 tentang Peradilan Agama.

${ }^{25}$ Takdir Rahmadi, 2012, Mediasi Penyelesaian Sengketa Melalui Pendekatan Mufakat, PT. Radja Grafindo Persada, Jakarta, hlm.194. 
Terdapat beberapa metode dan cara penyelesaian sengketa yang dilakukan dalam penyelesaian setiap perkara yang terjadi didalam masyarakat adat, antara lain sebagai berikut: ${ }^{26}$

1). Penyelesaian secara personal, yaitu penyelesaian yang dilaksanakan secara pribadi oleh tokoh masyarakat berdasarkan kepercayaan para pihak yang bersengketa tanpa melibatkan komponen lain.

2).Penyelesaian melalui pihak keluarga, yaitu penyelesaian yang dilakukan dengan pendekatan pihak keluarga dari pihak yang bersengketa yang biasanya memiliki hubungan yang lebih dekat.

3). Duek Ureung Tuha, yaitu musyawarah terbatas para tokoh masyarakat untuk menyelesaikan sengketa berdasarkan laporan para pihak yang bersengketa.

4). penyelesaian sengketa melalui Peradilan Gampoeng, yaitu peradilan adat yang diikuti oleh perangkat gampoeng untuk menyelesaikan sengketa yang dilaksankan di Meunasah atau Mesjid.

5). Penyelesaian melalui peradilan Mukim, yaitu peradilan adat yang diikuti oleh perangkat Mukim untuk menyelesaikan sengketa yang diajukan oleh para pihak yang bersengketa karena tidak puas terhadap keutusan peradilan Gampoeng.

Dalam pelaksanaan perjanjian Mawah, terkadang timbul sengketa atau masalah antara pihak pemilik harta dan pihak pengelola yang memerlukan penyelesaian. Timbulnya sengketa bermula dari pengaduan satu pihak yang berisi keberatan atau tuntutan hak atas harta tersebut dengan harapan dapat memperoleh penyelesaian sengketa secara adil sesuai dengan ketentuan peraturan yang berlaku. $^{27}$

Di kabupaten pidie, penyelesaian sengketa mawah dilaksanakan melalui musyawarah dan disaksikan oleh aparatur gampoeng, belum ada sengketa mawah yang sifatnya serius dan sampai melalui tingkat pengadilan dalam penyelesaiannya. Apabila sengketa tersebut tidak bisa diselesaikan secara kekeluargaan, maka para pihak yang bersengketa meminta bantuan kepada pihak ketiga dalam

\footnotetext{
2021.

${ }^{26}$ Abdul Hadi, Ketua Majelis Adat Aceh Kabupaten Pidie, Wawancara tanggal 12 Juli

27 Syahbuddin, Geuchiek Gampoeng, Wawancara tanggal 17 Juli 2021.
} 
menyelesaikannya, misalnya Lembaga Adat, seperti Keuchiek, Tuha Peut dan para aparatur desa, apabila permasalahan tersebut tidak bisa diselesaikan ditingkat gampoeng maka penyelesaian sengketa tersebut diajukan ketingkat Mukim atau Camat. ${ }^{28}$ Penyelesaian sengketa seperti ini juga disebut penyelesaian sengketa nonLitigasi, yaitu penyelesaian sengketa yang dilakukan diluar pengadilan. Menurut Fazliah salah seorang yang pernah menyelesaikan sengketa mawah di lembaga peradilan adat gampong berpendapat bahwa "penyelesaian sengketa secara musyawarah telah dilakukan di Kecamatan Indrajaya Kabupaten Pidie secara turun temurun, hal ini dilakukan karena sebagian masyarakat yang melakukan praktek mawah tidak paham akan hukum, sehingga apabila terjadi sengketa dalam proses praktek mawah, kami menyelesaikannya dengan cara musyawarah dan mengakui keputusan yang dihasilkan dari musyawarah tersebut". ${ }^{29}$

Pelaksanaan penyelesaian sengketa mawah di Kabupaten Pidie dilaksanakan berdasarkan adat kebiasaan yang berlaku didalam lingkungan masyarakat. Oleh karena itu permasalahan dapat terjadi apabila dalam proses pelaksanaan praktek mawah salah satu pihak melakukan wanprestasi atau melanggar perjanjian yang telah disepakati. Bentuk perjanjian yang diterapkan hanya kesepakatan para pihak yang melakukan praktek mawah yang dilakukan secara lisan, tidak adanya saksi maupun akta otentik sehingga apabila terjadi sengketa maka para pihak yang melakukan praktek mawah menyelesaikannya dengan cara musyawarah. ${ }^{30}$

Undang-Undang Nomor 30 Tahun 1999 tentang Arbitrase dan Alternatif Penyelesaiann Sengketa Pasal 6 ayat (1) menyebutkan bahwa sengketa atau beda pendapat dapat diselesaikan melalui alternatif penyelesaian sengketa yang didasarkan pada itikad baik dengan mengesampingkan penyelesaian secara Litigasi di Pengadilan Negeri. Di Kabupaten Pidie penyelesaian sengketa mawah dilakukan melalui musyawarah dan disaksikan oleh aparatur gampoeng, penyelesaian sengketa seperti ini juga dinamakan dengan penyelesaian sengketa non-litigasi,

28 Abdul Hadi, Ketua Majelis Adat Aceh Kabupaten Pidie, Wawancara tanggal 12 Juli 2021.

${ }^{29}$ Fazliah, Pihak yang Bersengketa, Wawancara tanggal 17 Juli 2021.

30 M. Hasan, Geuchiek Gampong, Wawancara tanggal 14 Juli 2021. 
yaitu penyelesaian sengketa yang dilakukan diluar pengadilan. Penyelesaian sengketa di Kabupaten Pidie dilakukan melalui negosiasi dan konsiliasi dalam suatu musyawarah antara para pihak untuk mencapai kesepakatan bersama yang disaksikan langsung oleh aparatur gampoeng. ${ }^{31}$

Penyelesaian sengketa melalui musyawarah dapat dilihat Pasal 14 ayat (2) Qanun Aceh Nomor 9 Tahun 2008 tentang Pembinaan Kehidupan Adat dan Adat Istiadat yang menyebutkan bahwa penyelesaian sengketa secara adat di Gampong atau nama lain sebagaimana dimaksud pada ayat (1) dilaksanakan oleh tokoh-tokoh adat yang terdiri atas:

a. Keuchiek atau nama lain.

b. Imuem Meunasah atau nama lain.

c. Tuha Peut atau nama lain.

d. Sekretaris Gampong atau nama lain.

e. Ulama, cendikiawan dan tokoh-tokoh adat lainnya di gampong atau nama lain yang bersangkutan,sesuai dengan kebutuhan.

Penyelesaian sengketa mawah di Kabupaten Pidie sebenarnya sama dengan penyelesaian sengketa pidana ringan maupun perdata yaitu harus ditempuh melalui peradilan adat gampong dengan prinsip perdamaian. Penyelesaian sengketa mawah mengikuti prosedur penyelesaian sengketa seperti prosedur sengketa lainnya dengan bentuk pelaksanaan seperti peradilan umum, yaitu dengan menempuh jalur pada tingkat Gampong melalui Keuchiek dan perangkat adat lainnya atau pada tingkat Mukim melalui perangkat adat lainnya. ${ }^{32}$ Namun penyelesaian sengketa mawah di Kabupaten Pidie diselesaikan dengan beberapa cara tergantung pada kendala yang dihadapi, adapun cara penyelesaian yang dilakukan umumya dilakukan secara kekeluargaan, yaitu penyelesaian sengketa yang dilakukan dengan cara musyawarah untuk memperoleh kata sepakat dalam penyelesaian sengketa secara damai. ${ }^{33}$

\footnotetext{
${ }^{31}$ Husaini, Tuha Peut Gampong, Wawancara tanggal 6 Juli 2021.

32 Abdul Hadi, Ketua Majelis Adat Aceh Kabupaten Pidie, Wawancara tanggal 12 Juli 2021.

${ }^{33}$ Zulkifli, Tuha Peut Gampoeng, Wawancara tanggal 17 juli 2021.
} 
Dalam penyelesaian sengketa yang dilakukan secara kekeluargaan, ada penyelesaiannya yang dilakukan oleh kedua belah pihak saja, yaitu antara pemilik harta benda dan si pengelola harta benda tersebut dan ada juga yang harus melibatkan Lembaga Adat yaitu Keuchiek atau Imuem Meunasah. Biasanya penyelesaian sengketa yang melibatkan lembaga adat adalah penyelesaian yang dikarenakan tidak ditemukannya kesepakatan antara kedua belah pihak yang bersengketa atau besarnya masalah yang dihadapi diantara kedua belah pihak yang bersengketa. $^{34}$

Berdasarkan Undang-Undang Nomor 30 Tahun 1999 tentang Arbitrase dan Alternatif Penyelesaian Sengketa dan Qanun Aceh Nomor 9 Tahun 2008 tentang Pembinaan Kehidupan Adat dan Istiadat penyelesaian sengketa mawah di Kabupaten Pidie yang dilakukan secara musyawarah dihadapan aparatur Gampong memiliki kekuatan hukum dan diakui keputusannya.

Sebelum persidangan digelar, Keuchiek dan perangkatnya (Sekretaris Keuchiek atau Sekretaris gampoeng, Tuha Peut, Imuem Meunasah, dan kadus atau kepala lorong melakukan pendekatan untuk dimusyawarahkan terhadap kedua belah pihak. Dalam rapat ini, diambil langkah-langkah dan tindakan untuk mencegah melebarnya masalah sengketa. Salah satu langkah awal yang diambil adalah mengadakan pendekatan kepada para pihak, supaya sengketa bisa diselesaikan secara perdamaian di Gampong dan biasanya kewibawaan fungsionaris lembaga adat dapat melunakkan para pihak yang bersengketa untuk bersedia diselesaikan secara adat. ${ }^{35}$

Dalam proses penyelesaian sengketa, tidak menutup kemungkinan terjadinya kekerasan antar pihak yang bersengketa, dalam hal ini Keuchiek langsung mengambil tindakan yaitu dengan mendatangi pihak yang bersengketa dan bila perlu mengamankan salah satu pihak di rumah Keuchiek dan biasanya para pihak lain tidak akan mengganggu lagi. Pendekatan tersebut bertujuan untuk mengetahui duduk perkara yang sebenarnya dan sekaligus menanyakan kesedian

\footnotetext{
${ }^{34}$ Murni, Pihak yang Bersengketa, Wawancara tanggal 6 Juli 2021.

35 Pasal 17 ayat (2) huruf c Peraturan Gubernur Aceh Nomor 60 Tahun 2013 tentang pelaksanaan penyelesaian sengeta atau perselisihan adat dan adat istiadat.
} 
pihak yang bersengketa untuk menyelesaikan perkaranya secara damai. Pada saat pendekatan tersebut, para pelaksana peradilan adat akan menggunakan berbagai metode mediasi dan negosiasi sehingga kasus ini dapat segera diselesaikan. ${ }^{36}$

Keuchiek sebagai pimpinan dan penanggung jawab sidang yang dibantu oleh perangkat Gampong sperti Tuha Peut, diharuskan sangat pro aktif dalam mencari atau mengkaji pokok-pokok masalah dan sekaligus memberi arahan atau petunjuk agar dapat menerima bukti-bukti kebenaran dalam setiap pemeriksaan sengketa dengan berpegang atau mengedepankan asas-asas perdamaian demi kerukunan dan ketentraman. Dalam proses persidangan tersebut dapat disimpulkan pokok sengketa dan sekaligus dapat menerapkan norma-norma hukum yang diperlukan sebagai landasan memberikan putusan yang dapat diterima secara damai oleh kedua belah pihak yang bersengketa. ${ }^{37}$

Apabila kesepakatan secara damai telah disetujui oleh kedua belah pihak yang bersengketa, maka sekretaris Keuchiek akan megundang secara resmi kedua belah pihak yang bersengketa untuk menghadiri persidangan pada hari dan tanggal yang telah ditetapkan. Apabila persoalan penjajakan atau mencari keterangan sudah ditemukan dengan segala bukti, maka Keuchiek mengadakan musyawarah dengan perangkat Gampong di Meunasah dan kadang-kadang sekaligus dengan para pihak yang bersengketa, para pihak yang bersengketa dipanggil dalam sidang musyawarah untuk melakukan proses pemeriksaan secara terbuka (internal Gampong). Apabila proses pendekatan untuk menyelesaikan sengketa banyak hambatan, kadang-kadang sidang musyawarah tidak cukup sekali melainkan harus beberapa kali yang harus disertai dengan saksi-saksi. Misalnya menyangkut dengan sengketa warga antar Gampong. ${ }^{38}$

Pemeriksaan duduk perkara merupakan kegiatan yang dilakukan dengan memanggil kedua belah pihak yang bersengketa untuk dimintai keterangan tentang persengketaan yang terjadi. Pemanggilan kedua belah pihak yang bersengketa dilakukan secara terpisah, kecuali dalam perkembangan sudah memungkinkan

\footnotetext{
${ }^{36}$ Zulkifli, Tuha Peut Gampong, Wawancara tanggal 17 Juli 2021.

${ }^{37}$ Samsul Ambia, Geuchiek Gampong, Wawancara tanggal 10 Juni 2021.

${ }^{38}$ Sulaiman Daud, Tuha Peut Gampong, Wawancara tanggal 10 Juni 2021.
} 
dihadirkan kedua belah pihak secara bersamaan. Pada saat persidangan berlangsung, para pihak yang yang bersengketa yaitu pelapor dan terlapor dihadirkan. ${ }^{39}$ Persidangan bersifat resmi dan tertutup, forum persidangan terutama posisi atau tata letak duduk para pihak yang bersengketa dan para pihak pelaksana peradilan adat disusun sedemikian rupa sehingga kelihatan formil secara adat.

\section{d. Penyelesaian Sengketa Mawah di Kabupaten Pidie Ditinjau Dari Hukum Islam}

1). Penyelesaian Melalui Jalur Perdamaian

Damai mempunyai beberapa makna yang berbeda, konsep damai membawa efek yang positif. Hampir tidak ada orang yang menentang perdamaian. Sebuah definisi sederhana dan sempit dari damai adalah ketiadaan sengketa, damai dapat terjadi secara suka rela dimana peserta perang memilih untuk tidak masuk dalam keributan, atau dapat dipaksa dengan siapa yang menyebabkan gangguan. ${ }^{40}$

Para ulama membolehkan dilakukannya perdamaian dalam penyelesaian sengketa secara adat. ${ }^{41}$ Hal ini berdalil dalam firman Allah SWT dalam surat AlHujarat ayat 9 yang artinya: "Dan jika ada dua golongan dari orang-orang mukmin berperang maka damaikanlah antara keduanya. Jika salah satu dari kedua golongan itu berbuat aniaya terhadap golongan yang lain maka perangilah golongan yang berbuat aniaya itu sehingga golongan itu kembali kepada perintah Allah, jika golongan itu telah kembali (kepada perintah allah), maka damaikanlah antara keduanya dengan adil dan berlaku adillah. Sesungguhnya Allah menyukai orangorang yang adil".

Secara yuridis, penyelesaian sengketa secara damai melalui fungsionaris adat sudah dibakukan didalam beberapa peraturan daerah di Provinsi Aceh. Secara formal pada awalnya dibakukan dalam Perda Nomor 7 Tahun 2000 tentang Penyelenggaraan Kehidupan Adat. Perda ini mengkehendaki bahwa sengketasengketa yang terjadi didalam masyarakat terlebih dahulu diselesaikan secara adat

\footnotetext{
${ }^{39}$ Muntazar Ali, Imuem Meunasah, Wawancara tanggal 10 juni 2021.

${ }^{40} \mathrm{http} / \mathrm{www}$. Wikepedia.org/Damai. Diakses tanggal 16 April 2014.

${ }^{41}$ Ridwan Ismail, Imuem Chiek Mesjid, Wawancara tanggal 9 Juli 2021.
} 
pada tingkat gampong dan mukim sebagai tindak lanjut untuk berfungsinya lembaga adat dalam menyelesaikan sengketa didalam masyarakat. Dalam dua Qanun tentang Pemerintahan Gampong dan Mukim yaitu Qanun Nomor 5 Tahun 2003 tentang Pemerintahan Gampong dan Qanun Nomor 4 Tahun 2003 tentang Pemerintahan Mukim secara jelas dijelaskan bahwa fungsi Geuchiek sebagai hakim perdamaian dalam menyelesaikan sengketa didalam masyarakat dan Mukim sebagai pemimpin Majelis Adat Mukim untuk menyelesaikan sengketa dalam masyarakat.

Untuk menyelesaikan masalah mengenai sengketa mawah di Kabupaten Pidie ada beberapa metode yang digunakan untuk menyelesaikannya. Secara umum sengketa adat mawah tidak pernah masuk ke Majelis Adat Aceh, karena semua konflik yang terjadi didalam masyarakat biasanya sudah berhasil ditangani ditingkat gampong dan mukim, memang sengketa adat berkaitan dengan mawah sering terjadi dikalangan masyarakat di Kabupaten Pidie, namun semuanya itu berhasil diselesaikan dengan baik dan secara damai ditingkat gampong. ${ }^{42}$

Sengketa adat khususnya mawah memang jarang terjadi di Kabupaten Pidie, akan tetapi jika memang ada persoalan dan persengketaan maka para pihak terkait akan menyelesaikannya secara musyawarah. Dan jika dalam proses musyawarah tidak didapatkan titik temunya maka para pihak terkait akan membawa masalah ini ke Imuem Meunasah, dan apabila persengketaan tidak juga dapat diselesaikan ditingkat Iтиет Meunasah sebagai perangkat pengadilan adat ditingkat Gampong maka persengketaan akan dibawa kepada perangkat adat yang lebi tinggi yaitu Imиem Mukiem selaku pengadilan adat ditingkat Mukim, dan biasanya persengketaan berhasil diselesaikan secara damai dipengadilan adat tingkat mukim. ${ }^{43}$

Terjadinya sengketa biasanya disebabkan oleh pihak yang mempunyai harta benda, pihak yang mempunyai harta benda biasanya berulah atau mengingkari janjinya dengan pihak pengelola, hal ini terjadi karena pihak yang punya harta benda mempunyai sifat kapitalis yang berlebihan terhadap hasil pembagian yang

42 Abdul Hadi, Ketua Majelis Adat Aceh Kabupaten Pidie, Wawancara tanggal 12 Juli

43 Abdul Mukhti, Imuem Chiek Mesjid, Wawancara tanggal 9 Juli 2021. 
didapatnya. Hal inilah yang biasanya menyebabkan terjadinya sengketa, apabila terjadinya sengketa diantara kedua belah pihak maka biasanya diselesaikan dulu oleh kedua belah pihak yang bersengketa dengan cara mufakat dan damai. ${ }^{44}$

Apabila dalam proses mufakat tidak ditemukan jalan untuk menyelesaikan sengketa, maka kedua belah pihak yang bersengketa akan membawanya ketingkat desa (gampong) untuk diselesaikan oleh pemangku adat atau pengadilan adat tingkat gampong, dan apabila sengketa tidak bisa diselesaikan ditingkat gampong maka akan dibawa ketingkat mukim atau pengadilan adat mukim untuk diselesaikan, biasanya persengketaan bisa diselesaikan secara damai ditingkat gampong dan jarang sampai ke pengadilan adat mukim. ${ }^{45}$

\section{2). Penyelesaian Melalui Lembaga Peradilan Adat}

Dalam sistem hukum di Indonesia, hukum adat merupakan salah satu hukum pelengkap. Begitu juga halnya di Aceh, hukum adat merupakan bagian dari sistem hukum nasional, dimana dalam hubungannya satu dengan lainnya tunduk kepada peraturan perundang-undangan juga tunduk kepada ketentuan hukum adat. Disamping kedua norma tersebut, dalam kehidupan bermasyarakat juga tunduk kepada ketentuan adat yang merupakan ciri khas daripada sistem hukum Adat yang berlaku didalam kehidupan masyarakat Aceh. Hukum Adat dan adat tersebut telah melembaga sejak masa kesultanan Aceh yang telah disesuaikan dengan filosofi Hukum Islam “Adat bak Poe Teumeureuhom, Hukom bak Syiah Kuala” sehingga sukar dibedakan antara Qaidah hukum adat dan Hukum Islam. ${ }^{46}$

Prinsip umum yang dianut oleh peradilan Adat di Aceh adalah tidak boleh membuka aib orang dan harus menjaga kewibawaan orang lain serta menjaga orang lain dari rasa malu terhadap sesuatu yang cemar dalam pandangan umum, hal ini

\footnotetext{
${ }^{44}$ Mahmud, Pihak yang Bersengketa, Wawancara tanggal 10 Juni 2021.

${ }^{45}$ M. Zaini, Aparatur Desa, Wawancara tanggal 17 juli 2021.

${ }^{46}$ Amrullah, Peradilan Adat Aceh dan Administrasi, Cipta Sarana, 2003
} 
secara khusus dinamakan dengan istilah toep aieb (tutup aib) dalam praktek peradilan Adat di Aceh. Kaidah tersebut menitikberatkan supaya dalam proses peradilan adat kedua hal tersebut tidak terjadi dan dapat dilokalisir, dengan demikian para pihak yang melakukan persengketaan dapat ditutupi aibnya. ${ }^{47}$

Adapun dalil terhadap perintah menutup aib orang lain adalah Hadis Rasulullah SAW yang artinya: "Barang siapa yang meringankan (menghilangkan) kesulitan seorang muslim kesulitan-kesulitan duniawi, maka Allah akan meringankan (menghilangkan) baginya kesulitan di akhirat kelak. Barang siapa yang memberi kemudahan bagi orang yang mengalami kesulitan di dunia, maka Allah akan memudahkan baginya kemudahan (urusan) di dunia dan di akhirat. Dan barang siapa yang menutupi (aib) seorang muslim sewaktu di dunia, maka Allah akan mentup (aibnya) di dunia dan di akhirat. Sesunnguhnya Allah akan senantiasa menolong seorang hamba yang selalu menolong saudaranya”. (HR. Tirmidzi)

Dalam praktek penyelesaian sengketa mawah di Kabupaten Pidie, para pihak yang mempunyai wewenang dalam melaksanakan peradilan adat harus sebisa mungkin mencari cara supaya diantara kedua belah pihak yang bersengketa tidak terbuka aibnya dalam pelaksanaan penyelesaian sengketa di lembaga peradian adat. ${ }^{48}$ Sengketa mawah yang pernah diselesaikan dalam hal ini adalah sengketa yang terjadi antara pemilik sawah dan petani penggarap, dimana pemilik sawah meminta bagian yang lebih besar dan tidak sesuai dengan perjanjian yang telah ditetapkan sebelumnya. Dalam hal ini petani penggarap merasa keberatan atas bagian yang diminta oleh pemilik sawah. Merasa tidak adil maka petani penggarap mengadukan perkara ini kepada Geuchik dan Imuem Meunasah. Penyelesaian sengketa ini diselesaikan terlebih dahulu dengan cara mufakat dan damai diantara kedua belah pihak yang bersengketa, karena jika diselesaikan secara langsung dilembaga peradilan adat gampong sudah pasti hal ini akan diketahui oleh masyarakat dan akan membawa efek malu terhadap pihak yang bersengketa. ${ }^{49}$ Dari permasalahan ini dapat dilihat bahwa dalam proses penyelesaian sengketa, para

\footnotetext{
${ }^{47}$ Tgk. Rasyidin Ahmad, Tokoh Agama, Wawancara tanggal 4 Juni 2021.

${ }^{48}$ Tgk. Rasyidin Ahmad, Tokoh Agama, Wawancara tanggal 4 Juni 2021.

49 Mahmud, Pihak yang bersengketa, Wawancara tanggal 10 Juni 2021.
} 
pihak penyelenggara peradilan adat sangat mempertimbangkan agar dalam proses penyelesaian sengketa para pihak terkait tidak terbuka aibnya.

\section{Kesimpulan}

Penyelesaian sengketa baik pidana ringan maupun perdata (termasuk mawah) di Kabupaten Pidie harus ditempuh melalui peradilan adat gampong dengan prinsip mufakat dan perdamaian. Penyelesaian sengketa mawah di Kabupaten Pidie mengikuti prosedur penyelesaian sengketa seperti prosedur sengketa lainnya dengan bentuk pelaksanaan seperti peradilan umum, dalam hal ini menempuh jalur pada tingkat gampong melalui geuchiek dan perangkat adat lainnya atau diselesaikan pada tingkat mukim melalui perangkat adat lainnya. Akan tetapi banyak kendala yang dihadapi oleh para geuchiek maupun peradilan adat tingkat mukim dalam penyelesaian sengketa mawah di Kabupaten Pidie seperti kurangnya bukti untuk diselesaikan, belum adanya qanun khusus tentang mawah dan SDM yang belum memadai, kurangnya bukti secara tertulis juga menjadi kendala besar untuk menyelesaikan sengketa mawah sehingga sengketa mawah bisa memakan waktu yang panjang dalam penyelesaiannya.

Penyelesaian sengketa mawah pada peradilan adat gampong di Kabupaten Pidie telah sesuai dengan penyelesaian sengketa dalam Islam yaitu dengan menempuh jalur arbitrase (tahkim). Penyelesaian sengketa mawah melalui peradilan adat secara sifat yaitu tahkim, namun mekanisme pelaksanaan penyelesaian sengketanya seperti konsep peradilan (Al-Qada). Penyelesaian sengketa dengan bantuan melalui geuchiek akan ditempuh dan jika tidak berhasil selanjutnya akan diselesaikan oleh lembaga peradilan adat yang lebih tinggi yaitu Lembaga peradilan adat mukim. Keputusan yang diambil perangkat adat sesuai dengan kebiasaan (adat) dan tidak bertentangan dengan Syariat Islam. Peningkatan kemampuan geuchiek dalam menyelesaikan sengketa harus diperhatikan sehingga lebih berkompeten mengadili perkara-perkara adat, aspek hukum harus diperjelas dengan membentuk aturan khusus (qanun) untuk perjanjian mawah sehingga sebabsebab terjadinya sengketa dapat diminimalisir. Perangkat adat yang mempunyai wewenang dalam menyelesaikan sengketa berupaya untuk menyelesaikan sengketa 
mawah yang terjadi melalui geuchiek atau mukim, namun apabila dari kedua alternatif penyelesaian sengketa tersebut belum juga dapat diselesaiakan maka para pihak yang bersengketa dapat menyelesaikannya melalui Lembaga Peradilan (Mahkamah Syar'iyah).

\section{Daftar Pustaka}

\section{a. Buku}

Abu Zakaria bin Yahya-Nawawi, 2009, Mugni Al-Muhtaj, dikutip dari Syahrial Abbas, Mediasi Dalam Perspektif Hukum Syariah, Hukum Adat, dan Hukum Nasional, Jakarta, Kencana.

Abdul Aziz Dahlan et al, 1997, Ensiklopedia Hukum Islam, PT. Ichtiar Baru Van Hoeve, Jakarta.

Abdul Halim, 2016, Peradilan Agama dalam Politik Hukum di Indonesia, Jakarta, PT. Grafindo Persada, Jakarta.

Abdul Manan, 2012, Hukum Ekonomi Syariah Dalam Perspektif Kewenangan Peradilan Agama, Kencana Prenada Media, Jakarta.

Amrullah, 2003, Peradilan Adat Aceh dan Administrasi, Cipta Sarana.

Aris Bistania, Hukum Acara Peradilan Agama dalam Kerangka Fiqh al-Qadha, PT. Raja Grafindo Persada, Jakarta.

AW Munawir, 1984, Kamus Al-Munawir, Pondok Pesantren Al-Munawir, Yogyakarta.

Frans Hendra Winarta, 2012, Hukum Penyelesaian Sengketa Arbitrase Nasional Indonesia dan Internasional, Sinar Grafika, Jakarta.

Rachmadi Usmani, 2012, Mediasi di Pengadilan: Dalam Teori dan Praktik, sinar Grafika, Jakarta.

Salam Madkur, 1964, Al-Qadha' fi al-Islam, Dar al-Nahdhah al-Arabiyah, Kairo.

Takdir Rahmadi, 2012, Mediasi Penyelesaian Sengketa Melalui Pendekatan Mufakat, PT. Radja Grafindo Persada, Jakarta. 
Yusna Zaidah, 2015, Penyelesaian Sengketa Melalui Peradilan dan Arbitrase Syariah di Indonesia, Aswaja Pressindo, Yokyakarta.

\section{b. Peraturan Perundang-Undangan}

Qanun Aceh Nomor 9 Tahun 2008 tentang Pembinaan Kehidupan Adat dan Adat Istidatat.

Qanun Aceh Nomor 10 Tahun 2008 tentang Lembaga Adat

Peraturan Gubernur Aceh Nomor 60 Tahun 2013 tentang Pelaksanaan Penyelesaian Sengeta atau Perselisihan Adat dan Adat Istiadat.

\section{c. Tesis/Jurnal/Makalah}

Abdurrahman, 2014, "Praktek Mawah melalui Mudharabah dalam Masyarakat Aceh”, Tesis, Magister Hukum Fakultas Hukum Universitas Sumatera Utara, Medan.

Rahma Ismail, "Mekanisme Penyelesain Pertikaian Alternatif dan Perbandingannya dengan Islam", Makalah Undang-Undang Jilid 1, UKM, Bangi, 2003.

Rika Lestari, "Perbandingan Hukum Penyelesaian sengketa Secara Mediasai di Pengadilan dan di Luar Pengadilan di Indonesia”, Jurnal Ilmu Hukum,Vol.3, No.2. 